\title{
Visual Self-Presentation Strategies of Greek Political Leaders through their YouTube Political Advertisements for the 2019 EU Elections \\ Anastasia Veneti and Petros loannidis
}

Anastasia Veneti, Bournemouth University

aveneti@bournemouth.ac.uk

Petros loannidis, aboutpeople

petros@aboutpeople.gr

For citation:

Veneti, A., loannidis, P. Visual Self-Presentation Strategies of Greek Political Leaders through their YouTube Political Advertisements for the 2019 EU Elections. In: A. Veneti and A. Karatzogianni (eds) The Emerald Handbook of Digital Media in Greece: Journalism and Political Communication in Times of Crisis, pp. Bingley: Emerald (in press)

Dr Anastasia Veneti is Principal Academic in the Faculty of Media and Communication at Bournemouth University (UK) and Program Leader of the MA International Political Communication. Her research lies in the intersection of media and politics, including political communication, digital political campaigning, media framing, protests and social movements, visual communication and photojournalism. Her work has been published in various edited volumes and academic journals. She is the author of Political Advertising and Citizens' Perceptions (Nisos, 2009 in Greek) and co-editor (with D. Jackson and D. Lilleker) of Visual Political Communication (Palgrave, 2019).

Petros loannidis is a political analyst and the founder of aboutpeople, a polls company in Athens, Greece. He studied politics and communication and the University of Lancaster and City University, London. He is the author of 2009, The Last Elections of Metapolitefsis, Athens Voice Books, and co-editor of 2019, The First Elections after the Memorandum, Papazisis Publications. He has published a series of articles in various Greek media outlets. 


\section{ABSTRACT:}

Drawing on the theoretical framework of Grabe \& Bucy (2009), this chapter presents the findings of an exploratory study concerning the visual self-presentation strategies that the political leaders of the two main political parties in Greece (Syriza and New Democracy) employed in their political adverts on YouTube during the campaign for the 2019 European Parliamentary elections. The findings illustrate that, despite the fact that both leaders made equal use of the two master frames of the ideal candidate and the populist campaigner, their visual strategies differed in the emphasis given to the various subdimensions of the visual framework. Both leaders attempted to project a public persona characterised by ordinariness and professionalism. Tsipras used a series of spots through which he sought to both 'renew' his relationship with the electorate, and reinforce perceptions of his statesmanship as a widely respected political leader. Mitsotakis' visual strategy was primarily based on building a more relatable image and strengthening his leadership profile, as well as the frequent use of patriotic symbols.

\section{KEYWORDS:}

1. Visual self-presentation strategies

2. YouTube political advertisements

3. 2019 EU elections

4. Political leaders

5. Greece

6. Political campaigns 


\section{Introduction}

Research on the visual aspects of political communication and campaigning has gained increasing momentum among academics (Schill, 2012; Grabe \& Bucy, 2009; Holtz-Bacha \& Johansson, 2017; Russmann \& Svensson, 2017; Veneti, Jackson \& Lilleker, 2019). Various studies have demonstrated the resonant power of images to evoke strong emotions (Coleman \& Wu, 2015; Lilleker, 2019), to act as a source of political information that can be processed quickly and be more memorable (Graber, 1996; Bucher \& Schumacher, 2006), and to shape attitudes and behaviours (Lilleker, 2019; Rosenberg et al., 1986). As Lilleker $(2019$, p.39) argues 'Imagery can be used to portray ideal roles, behaviors and the norms of a given society, for example, how a world leader should look or what makes a leader appear more authentic, honest, decisive or competent'. Supporting such arguments, other studies have shown that voters rely on visual cues, such as politicians' physical attractiveness, when assessing candidates' character traits and making voting-related decisions (Ahler, Citrin, Dougal \& Lenz, 2017; Banducci, Karp, Thrasher \& Rallings, 2008). Given that visual representation plays a crucial role in election campaigns, political candidates engage in unremitting struggles to use visual frames that present them positively and that can convince voters to support them (Grabe \& Bucy, 2009; Marland, 2012).

In the digital media era, political candidates have an abundance of opportunities to portray themselves through visual means that communicate directly with voters (Stanyer, 2008; Jackson \& Lilleker, 2011). Traditional forms of political marketing, such as political advertising, have evolved to address the needs of the new era. Alongside traditional 30-second filmed spots designed for television and posted online, so-called YouTube ads are among the most popular forms of contemporary political advertising (Vesnic-Alujevic \& Van Bauwel, 2014). As Grusin (2009, p. 66) argues 'YouTube produces a divergence of audience and message [...] fostering multiple points of view rather than the small number of viewpoints represented by broadcast television'. Launched in 2005, YouTube is now the biggest online video-sharing platform worldwide and one that political candidates seek to capitalizse on. Through such online advertising, politicians now possess considerable opportunities, both to manage their self-presentation and to reach a massive audience. However, there is a paucity of research on how political candidates utilise images to depict themselves on social media sites (Muñoz \& Towner, 2017).

Drawing on the theoretical framework of Grabe \& Bucy (2009), and other similar studies of visual representation (Muñoz \& Towner, 2017; Goodnow, 2013; Lilleker \& Koc-Michalska, 2013), this chapter presents the findings of an exploratory study of the visual self-presentation strategies that the political leaders of the two main political parties in Greece (namely Syriza and New Democracy) employed during the electoral campaign of the 2019 European Parliamentary elections. As evidenced by various studies, Greece makes a particularly interesting case study for such exploration, as it has slowly but consistently adopted new media technologies in political campaigning (Poulakidakos \& Giannouli, 2019; Jackson et al., 2019; Deligiaouri, 2011; Deligiaouri \& Symeonidis, 2010. For an overview of the professionalisation of political communication in Greece see: Papathanasopoulos, 2007). This 
research is based on both a qualitative and a quantitative content analysis of the political advertisements uploaded on both parties' official YouTube channels.

\section{The Greek political system and the EU elections}

Greece is a presidential parliamentary republic with a multi-party system. The Prime Minister of Greece is the head of government. The Greek Parliament has 300 members, elected for a four-year term by a reinforced proportional representation election system. Local and national elections are held every four years in Greece. Following the outbreak of the economic crisis in 2008 and the subsequent signing of the Greek bailout treaty in May 2010, Greece was characterised by deep political instability, which led to a subsequent restructuring of its political system. Following the results of the July 2019 national elections, the two main political parties are now New Democracy (ND Nea Dimokratia- the conservative party) which won the elections, and SYRIZA (Coalition of the Radical Left), the main opposition party. Beyond these two parties, the Greek Parliament currently consists of the Kinima Allagis (the socialist party), the Greek Communist Party (KKE- Komounistiko Komma Ellados), MeRA25 (a left-wing political party), and Greek Solution (Elliniki Lisi, a right-wing populist party).

Research on contemporary Greek political parties has trended to be based and focus on strongly held beliefs that they are 'personal parties' (in that, they are closely identified with the personalities of their leaders), characterised by interlocking relationships with various stakeholders (Lyrintzis, 2007). Despite the fact that a sole focus on these characteristics does not do justice to a comprehensive understanding of the parties' idiosyncrasies, it is nonetheless the case that considerable research has served to underline the central importance in Greek politics of the role and the impact of the party leader on both the political direction of their party and its style of governance (for a closer examination of the roles of political leadership in Greece, see: Featherstone and Papadimitriou, 2019; Moschonas, 2002: 134-153; Moschonas, 2004). Given these facts, the focus of this study is on the self-presentation strategies of the two main political leaders, Alexis Tsipras (SYRIZA) and Kyriakos Mitsotakis (New Democracy), during the 2019 European Parliamentary elections. It is worth noting here, that the year of 2019 was an intensively busy political period for Greece, with three sets of elections being held; on $26^{\text {th }}$ May both Municipal and EU elections took place, followed by General elections on $7^{\text {th }}$ July. EU elections are widely viewed as a barometer for national politics, being referred to as 'national secondorder elections' (Reif \& Schmit, 1980). This was borne out by responses to the results of the European Parliament elections in May 2019 (in which SYRIZA lost considerable power), with Alexis Tsipras (the Greek PM at that time) immediately announcing a General Election (for the results see: European Parliament electoral results, 2019). A range of studies have illustrated that European elections in Greece are determined more by domestic than wider political cleavages, and are dominated by issues of national rather than European or international importance (Reif \& Schmit, 1980; Novelli et al., 2017). 


\section{Political Candidates' Self-Presentation and Visual Framing}

During election campaigns, candidates aim to create and communicate an appealing image of themselves in order to attract voters. As early as 1959, the sociologist Erving Goffman presented a theory of self-presentation, in his book, The Presentation of Self in Everyday Life. By employing a dramaturgical, theatre-like approach, to the study of human social interactions, Goffman argues that when an individual comes into contact with other people, they attempt to control the others' impressions, by 'fixing' his/her appearance and manner. Goffman's main interest was in understanding how, through the use of symbolic mechanisms, we shape the ways in which we are perceived by others. Goffman's theory of self-presentation has been widely used in recent political research on the digital media environment, such as the examination of political candidates' websites (Stanyer, 2008; Lilleker \& Koc-Michalska, 2013) and their social media profiles (Colliander et al., 2017; Jackson \& Lilleker, 2011). In a comparative study, investigating the online self-presentation of American and British politicians, Stanyer (2008) found that members of the U.S. House of Representatives projected aspects of their private life more frequently than did their British counterparts. The explanation he provides is that U.S. politicians are more likely to focus on their personal qualities, as party loyalty is not as prevalent in the U.S. as it is in the UK. In another study, Jackson and Lilleker (2011) found that British MPs use Twitter both as a political marketing tool and as part of their impression management strategy. Their findings indicate that MPs tweeted about their everyday lives, their political views, and their personal preferences. In an experimental study on the use of Twitter by Swedish political candidates, Colliander et al. (2017) demonstrated that tweets that combine aspects of politicians' professional and private life increased voters' interest in the candidates and the likelihood of their voting for them.

Although these studies offer us valuable insights into the campaign communication strategies of candidates, they focus primarily on textual or verbal elements. Yet, social media platforms rely largely on visual communication (Gupta, 2013). Engagement with social media platforms, such as YouTube, Instagram, Snapchat, Tumblr, and Pinterest, has gained considerable momentum with consumers/voters. As such visual-centric media platforms offer new avenues for self-presentation and image management, there is a greater need to develop understandings of the role and impact that images play and possess in political campaigning (Muñoz \& Towner, 2017). Research on the selfpresentation of candidates has frequently utilised visual framing to investigate how candidates' build their public profiles. Visual framing draws on classic framing theory, as first articulated in Goffman's (1974) work, and examines how aspects of reality are perceived, in order to highlight and promote a particular interpretation of a specific event, issue or person (see also Entman, 1993). According to Hertog \& McLeod (2001) frames derive power from their symbolic significance, through their use of recognisable myths and metaphors in the narratives they promote. Images are powerful framing tools, because they are less intrusive than words and as such are less cognitively demanding. Therefore, when images are utilised in campaigning, it is more likely that peripheral rather than central processing in the brain may be activated, resulting in audiences being more likely to accept the visual frame without question (Rodriguez \& Dimitrova, 2011, p.50). 
In studying the portrayal of political actors in traditional television coverage during U.S. presidential election campaigns from 1992 to 2004, Grabe \& Bucy (2009) identified three visual frames: the ideal candidate, the populist campaigner, and the sure loser. They claim that the ideal candidate framing broadly consists of two dimensions, statesmanship and compassion; '[v]isual manifestations of statesmanship signal the mythic proportions of the presidency, projecting, power, authority, control and active leadership' (Grabe \& Bucy, 2009, p.102), whereas compassion is represented by linking candidates with 'social symbols of compassion such as children and families' (ibid., p. 104). As such, the political image of statesmanship is best projected through appearances with prominent peers and patriotic symbols, and appearances in formal attire. The populist campaigner frame is similar to that for the ideal candidate, being manifested in two dimensions: mass appeal and ordinariness. This framing builds on 'the idea that ordinary people, a noble troupe, stand in opposition to an aristocratic and self-serving elite' (ibid., p. 105). So, by embracing the populist campaigner frame, a candidate displays familiarity and intimacy with and understanding of the people. Mass appeal is communicated through the portrayal of massive audiences supporting the candidate or their associating with celebrities. Ordinariness is depicted by the candidate dressing in informal attire or sports clothing, interacting with ordinary people or undertaking physical activity (ibid., p. 107). The sure loser frame portrays candidates in unflattering situations (e.g. with negative facial expressions, such as frowning), and looks to highlight slipups in their campaign. Several researchers have applied Grabe and Bucy's (2009) approach in their examination of candidates' visual self-representation strategies. It is worth noting that the sure loser frame has not been used in these studies, as it is highly unlikely that candidates will purposefully present themselves in such a negative way.

Goodnow (2013) applied Grabe and Bucy's framework in a semiotic analysis of Obama's and Romney's use of Facebook photos during the 2012 U.S presidential election campaign. She discovered that both men, despite adopting different strategies, utlised the frames of the ideal and populist candidate. In a similarly focused study of Facebook photos, of Romanian candidates in the 2014 European elections, Cmeciu (2014) found that the ideal candidate frame was more prevalent than that of the populist campaigner. With reference to the ideal candidate frame, the compassion dimension was the dominant one, while the populist frame was mostly promoted through an emphasis on ordinariness. In discussing the use of the compassion dimension, Cmeciu (2014, p. 424) revealed that female candidates posted images depicting them interacting with children in an attempt to encourage the impression of a 'protective mother'. A series of researches, across different media platforms, electoral races and countries, have emphasised differences in the strategic use of the two master frames (ideal and populist). For instance, Lee (2016), in a crosscultural examination of presidential website photos of the former U.S President Obama and the South Korean President Lee Myung-bak, found that Obama relied mostly on compassion and mass appeal, while Myung-bak focused more on the ideal candidate dimension of statesmanship. In a more recent study of U.S. presidential primary candidates' Instagram profiles, Muñoz and Towner (2017) found that the ideal candidate frame was more popular than the populist frame.

Taking such discussions on the significance and popularity of Instagram in visual self-presentation strategies further, Poulakidakos and Giannouli (2019) examined the Instagram photos of the main political leaders in Greece. Their study revealed that the visual strategies of Kyriakos Mitsotakis (Conservative party Opposition Leader during the period of that study), and Alexis Tsipras (Radical left 
party leader and Prime Minister at the time of that study) differed significantly. Kyriakos Mitsotakis posted more personal and private photos than Alexis Tsipras. The latter focused more on developing a statesmanship profile that could promote the image of 'an effective, problem-solving and internationally accepted politician' (Poulakidakos \& Giannouli, 2019, p.202). The authors conclude that both leaders promoted a very positive self-image, by strategically avoiding attacks on their opponent and instead focusing on amiable images of themselves. Previous experimental research has revealed that voters prefer candidates with a more positive image (such as images with them smiling) than negative images (such as images of them looking annoyed) (Barrett \& Barrington, 2005).

As these studies suggest, campaigning online requires a careful consideration of the various digital platforms' architectures, as these in their turn influence decision making concerning effective visual strategies (as an example - the more personalised approach that works best on Instagram). With 1.9 billion users worldwide (Statista, 2019), YouTube has increasingly gained prominence in political campaigning. YouTube is a video-sharing website that appeared in the era of Web 2.0 and which started to be used for political communication in 2006, during the electoral campaign for the presidential primaries in the United States (Gueorguieva 2008). Given it is, by a considerable margin, the world's most used video-sharing platform, ever more politicians and political parties are increasingly using it for various purposes, online political advertising being amongst the most popular. By online political advertising, we refer to both traditional 30-second adverts designed for television that have been posted online, and a more recent form of advertising, so-called 'YouTube ads' (Ridout, Franklin Fowler \& Branstetter, 2010). Despite a vast literature on traditional political advertising (Kaid, 1998; Kaid \& Holtz-Bacha, 2006; Kaid \& Johnston, 2001) we know little about such, more recent, online political ads (Vesnic-Alujevic \& Van Bauwel, 2014).

Given the increasing importance of online political advertising, the disparities in politicians' visual strategies - as affected by diverse political cultures, and the important differences in usage due to different platforms' digital architecture - as manifested in various studies (Bossetta, 2018), this chapter investigates how the main Greek political leaders use online political advertising to promote specific images of themselves through a case study, exploring their YouTube Political Advertisements for the European Parliament 2019 Elections .

\section{Methodology}

To address our research objective, we conducted a qualitative and quantitative content analysis (Schram, 2014) of the political advertisements that the two major Greek political parties, namely New Democracy and SYRIZA, uploaded on their YouTube channels during the pre-electoral period leading up to the European Parliamentary elections in May 2019. The sample we analysed consisted of all the spots (both still images or video) that included the leaders of the two main parties (see Appendix): five spots by the New Democracy party portraying its leader Kyriakos Mitsotakis (Opposition leader during the elections and the current Greek Prime Minister) (New Democracy YouTube Channel., 2019), and 
fifteen spots by the SYRIZA party presenting its leader Alexis Tsipras (Prime Minister at that time, who lost the electoral race) (SYRIZA YouTube channel, 2019).

The analysis was conducted by both researchers over a period of two weeks in November 2019. Our unit of analysis was the video and its whole duration was examined and coded by both researchers. The data entry for the quantitative content analysis and the elaboration of the results was conducted with the use of SPSS 25.0 .

\section{Coding scheme}

In order to examine the visual self-representation strategies of the two Greek political leaders in the political advertisements on YouTube, we employed both a deductive and inductive framing analysis through a coding scheme with eight variables. We drew on Grabe and Bucy's (2009) visual framework, which was developed to analyse the visual strategy of U.S. presidential candidates in TV news coverage. We utilised their two dominant master frames of the ideal candidate and the populist campaigner.

However, in order to more appropriately address the idiosyncrasies of our particular study, we chose to adapt the variables that refer to the two dimensions of the ideal candidate frame; statesmanship and compassion. The final variables were formulated as follows: Statesmanship was measured using the following set of binary variables $(0=$ absence, 1 = presence): (a) Greek elected officials, (b) International politicians, (c) patriotic symbols, (d) identifiable entourage (reporters), (f) formal attire. Compassion was measured using the following variables: (a) children, (b) family associations, (c) admiring women, (d) religious symbols, (e) interaction with individuals, (f) physical embraces.

In a similar way, the populist campaigner frame which consists of the dimensions mass appeal and ordinariness was formulated as follows: The mass appeal was measured using the following binary variables: (a) celebrities, (b) large audiences, (c) interaction with crowds, and the Ordinariness was measured by using the variables: (a) casual dress, (b) athletic clothing, (c) ordinary people, (d) physical activity. Like other similar studies, we have not utilised the sure loser frame as this, unsurprisingly, was not used by candidates and as such is not relevant for this research (Goodnow, 2013; Muñoz \& Towner, 2017). Finally, in order to examine the cinematic techniques that the political leaders employed, we included the following three frames: Camera frame, which was examined through the following variables - (a) portrait, (b) medium distance, (c) long distance; Camera angle, examined through the following variables - (a) looking directly at the camera, (b) not looking at the camera, (c) mixed; and the Videostyle, examined through the following variables - (a) video (motion image), (b) use of still images, (c) mixed. 


\section{Findings and discussion}

Our data reveals that, contrary to similar studies (Goodnow, 2013; Cmeciu, 2014; Muñoz \& Towner, 2017), where candidates tended to seek to visually present themeselves as the ideal candidate, in the Greek case, candidates used both master frames equally. However, although both Tsipras and Mitsotakis utilised both of these master frames of the ideal candidate and populist campaigner, each candidate employed them in different ways with respect to the emphasis on their respective dimensions.

The visual self-presentation of Alexis Tsipras

As is obvious from the analysis of our data, Tsipras used elements from both master frames (ideal candidate and populist campaigner) equally frequently in his visual self-representation strategy. Table 1 (below) displays the number of cases in which each of the variables, relating respectively to the two dimensions associated with each of the master frames, were found in the party's political advertisements.

-Table 1 here-

The majority of SYRIZA spots were issue-specific political ads focusing on a range of topics, such as pensions, health, education, labour rights, etc. (see Appendix). With regard to the ideal candidate frame, Tsipras made use of both dimensions (statesmanship and compassion) to enhance his image as a strong and compassionate leader. As far as the first dimension, of statesmanship, is concerned; despite being well known for his casual dressing style, in the majority of these spots, Tsipras was presented in formal attire. Although the campaign did not include many spots where Tsipras was seen with other politicians, the ones that were posted on YouTube were very well curated, providing carefully selected images with well-known and significant political figures, such as António Costa, Prime Minister of Portugal, Udo Bullmann, MEP/ President of the European Socialists, Jesse Feras Klaver, Leader of GroenLinks, and the Pope. As Goodnow's (2013) study of Obama's photos reveals, this is quite a common tactic to deploy. Obama positively influenced public perceptions of his statesmanship, by being seen to be closely associated with other respected statesmen (Goodnow, 2013, p.1589). In a similar way, Tsipras sought to enhance public perceptions of his leadership, authority and international profile, through being seen to associated with other prominent European peers.

In terms of the focus achieved by the different technical aspects of their spots, SYRIZA predominantly utilised video to build the leadership profile of Tsipras, while still images were used to construct a more 'intimate' relationship with different publics. Overall, there were five spots with video, and ten spots with still images of Alexis Tsipras. These spots included videos in which Tsipras was mainly 
interacting with large and approving audiences, videos which featured other prominent European peers supporting him, and videos in which Tsipras was talking directly to the camera, full of confidence. As has been foregrounded in a range of similar studies (Goodnow, 2013; Muñoz \& Towner, 2017), the focus on the mass appeal dimension (relating to the populist campaigner frame), through the depiction of the candidate with large and approving audiences, is a frequently used one. As Cialdini (2006) argues, this constitutes a tactic of persuasion, which seeks to demonstrate 'social proof' of the candidate's popularity to voters.

With regard to the shooting style of these spots, in most of them, as a result of the style of SYRIZA video ads and their subsequent use of still images, Tsipras did not look directly at the camera. As Table 2 (below) shows, there are only four spots out of the 15 in which a mixed style has been adopted. In these, Tsipras was depicted, from a medium distance, walking, interacting with people, or talking to the camera.

- Table 2 here -

The main visual strategy adopted in the issue-specific spots was a focus on Grabe and Bucy's (2009) dimensions of compassion (ideal candidate frame), and ordinariness (populist campaigner frame). Each of these spots began with a presentation of either the government's achievements per sector, or prospective policies deemed to be favoured by the electorate, and concluded with a still image of Tsipras with relevant individuals or groups from the respective public that each spot was aimed at (e.g. older people when discussing pensions, nurses when discussing health etc.). Overall, Tsipras' photos were replete with images depicting him with ordinary people (13 out of 15 spots include such photos). Lots of these images included him engaging in physical embraces with these publics (handshakes and affinity gestures). In these issue-specific (themed) spots, the compassion and ordinariness dimensions are focused on in ways that allow a construction of Tsipras as possessing the profile of a compassionate leader, on two levels: (a) depicting him in physical interactions with ordinary people suggests an image of a leader that is easily accessible and relatable to (the various candid shots, and his natural unpolished style, facilitated such readings); (b) such perceived closeness to the people can then more easily be translated as being related to possessing an understanding of the people's needs and expectations, that is then reflected in the proposed policies of the party.

The visual self-presentation of Kyriakos Mitsotakis

As was the case with Tsipras, Mitsotakis utilised both master frames (ideal candidate and populist campaigner) equally, as Table 3 illustrates. However, the emphasis within the range of variables, with respect to the two dimensions of each of the frames, was different. 
Regarding the statesmanship dimension, Mitsotakis outscored Tsipras on the use of patriotic symbols. Specifically, the Greek flag was readily apparent in all of the spots in which Mitsotakis appears. The primary visual strategy, with respect to the portrayal of Mitsotakis, was defined by a focus on an ethno-centric dimension, an attempt to create a feeling of 'Greekness', and 'unity'. As evidenced by subsequent spots in the national election campaign a few months later, this is a strongly consistent, prominent and ongoing aspect of ND strategy (Veneti \& Poulakidakos, 2019). The frequent use of patriotic images as a means to build positive perceptions of a candidate's statesmanship amongst voters has been widely utilised by many politicians and political parties, and is particularly evident with respect to portrayals of leaders of conservative parties and the US Republican party. For instance, Goodnow (2013) argues that Mitt Romney's extensive use of patriotic images in the US was an attempt, by the presidential candidate, to borrow credibility from venerated symbols. Muñoz and Towner (2017) found that President Trump relied on images that associated him with patriotic symbols and large approving audiences more than any of the other presidential candidates.

The ideal candidate subdimension of statesmanship was further enhanced through what Grabe and Bucy $(2009$, p.102) call images of 'power, control, and active leadership'. Mitsotakis was depicted engaging in a variety of situations that reflected his leadership of the party, and his 'readiness' for the PM post. Such images included interaction with the potential MEPs of his party, giving speeches to large approving audiences, and him working in his office.

Drawing on Grabe and Bucy's (2009) subdimension of ordinariness, it is apparent that the leader of the conservative party sought to display images that suggested his closeness to the people. The spots were replete with images and videos of ordinary people interacting with the party leader. Some of them included him engaging in affinity gestures (e.g. physical embraces, handshakes, high-fives), suggesting a sincere interest in the people and their needs. A range of studies have illustrated that such gestures are common practice in political campaigning; US Democratic party presidential candidate Bernie Sanders and US President Donald Trump frequently post images that depict them gesturing with their hands. Sanders was frequently seen with arms outstretched to a crowd, and Trump is frequently seen giving a thumbs-up gesture in photos (Strand \& Schill, 2019; Muñoz \& Towner, 2017). In the case of Mitsotakis, who is generally considered part of the elite upper class, the ND visual strategy was designed to bridge this gap between his membership of elite and ordinary people. Such images raised the credibility of his claim to relate to the lives and needs of the average Greek voter.

This positive portrayal of Mitsotakis' relationship with the people was further enhanced by the camera angle used when filming him addressing audiences. Specifically, in three out of the five spots, a mixed approach was utilised that included shots of Mitsotakis making eye contact with the camera. Camera shots such as these are more engaging for viewers, since the subject is perceived to be looking directly at the people he is addressing. This, direct address to the viewer, creates what Kress and van Leeuwen (2006) call an image act; when 'the subjects create a vector with the viewers, thereby asking them to participate with them in their act' (Goodnow, 2013, p.1590). In this context, front-angle photos are usually interpreted by viewers as suggesting honesty (Goodnow, 2013). 
Resonating with similar studies (Reif \& Schmit, 1980; Novelli et al., 2017), we found that both sets of spots (those from ND and from SYRIZA) focused more on domestic issues, those viewed as of national importance, with only a secondary focus on connecting these domestic and national issues to the future of Greece in the EU. Comparatively, ND spots had a slightly greater focus on the European aspect of the EU elections, as in two out of the five spots, its leader was depicted along with the party's prospective MEPs.

\section{Concluding remarks}

This study provides a fuller and clearer understanding of how political leaders use YouTube political adverts to visually construct and communicate a desired image of their political selves. While similar studies (Goodnow, 2013; Cmeciu, 2014; Muñoz \& Towner, 2017) suggest that the ideal candidate frame is the most frequently used, our data shows that the Greek political leaders used both frames - ideal candidate and populist campaigner - equally. Such differences need to be appreciated as occurring within somewhat different contexts, given the different affordances that social media platforms offer for campaigning, compared to the utilisation of traditional technology and campaigning methods, with this being reflected in how they are being used differently in candidates' communication strategies (Jackson et al., 2019; Kreiss et al., 2018). In this context, YouTube political advertisements can be understood as being an amalgam of different elements that are borrowed from both traditional political advertising and contemporary social media practices. Moreover, such findings could possibly be a reflection of the rise of populism on both the right and the left across much of the globe in recent years.

Despite the fact that both leaders utilised the two master frames (ideal candidate and popular campaigner) almost equally, their visual strategies for campaigning on YouTube differed significantly in the emphasis each gave to the various subdimensions of Grabe and Bucy's (2009) visual framework (for the ideal candidate framing, the dimensions of statesmanship and compassion; for the populist campaigner framing, the dimensions of mass appeal and ordinariness). As a common denominator, both political leaders attempted to project a public persona that was characterised by both ordinariness and professionalism/statesmanship (Langer, 2007). As research on Greek politicians' use of Instagram illustrates, there has been a growing momentum with regard to the use of social media in politicians' attempts to enhance public perceptions of their leadership skills (Poulakidakos \& Giannouli, 2019). Tsipras used a series of spots through which he sought to 'renew' his relationship with the electorate, and to reinforce perceptions of his statesmanship, as a globally recognised political leader. Mitsotakis' visual strategy had three distinct aspects: (a) an attempt to build a more relatable and accessible image; (b) the enhancement of perceptions of his leadership profile and his authority; (c) the construction of an image intended to project him as the 'protector' of national interests, through the frequent use of patriotic symbols. More broadly, the ND adopted a similar strategy for the campaign for the subsequent national elections (Veneti, 2020). Through the various visual frames that were utilised, both leaders tried to ensure that they communicated a public image that encouraged their audiences to view them as occupying a position of service to the country; a strong leader able to govern. It is important to take into consideration that our research is limited by the small sample size that consequently limits our ability to make broad generalisations. 
As such, it would be useful for future research to explore a larger sample, as well as provide a comparative approach as to the use of YouTube political ads in different countries, across different periods in the electoral cycle.

\section{Appendix}

\begin{tabular}{|l|l|l|l|}
\hline \multicolumn{4}{|l|}{ New Democracy Spots } \\
\hline No. & Title & Duration & Link \\
\hline 1 & ND long spot & $8: 43$ & https://www.youtube.com/watch?v=YXKtpSd4zlg \\
\hline 2 & $\begin{array}{l}\text { We deserve better In } \\
\text { Greece and Europe }\end{array}$ & $1: 49$ & https://www.youtube.com/watch?v=tWGqQfQzKp4 \\
\hline 3 & $\begin{array}{l}\text { Greece's future is to } \\
\text { begin now }\end{array}$ & $1: 13$ & $\underline{\text { https://www.youtube.com/watch?v=-b cNrpP0EI }}$ \\
\hline 4 & $\begin{array}{l}\text { Greece can make it. } \\
\text { Greeks can make it. }\end{array}$ & $6: 25$ & $\underline{\text { https://www.youtube.com/watch?v=Sj65 2DlgNs }}$ \\
\hline 5 & $\begin{array}{l}\text { Greece can make it. } \\
\text { Greeks can make it. }\end{array}$ & $1: 20$ & $\underline{\text { https://www.youtube.com/watch?v=-- }}$ \\
\hline
\end{tabular}

Source: Official New Democracy (ND) YouTube channel

\begin{tabular}{|l|l|l|l|}
\hline \multicolumn{3}{|l|}{ SYRIZA Spots } \\
\hline No. & Title & $\begin{array}{l}\text { Duration in } \\
\text { mins }\end{array}$ & Link \\
\hline 1 & $\begin{array}{l}\text { For the Greece of } \\
\text { many and people's } \\
\text { Europe }\end{array}$ & $7: 00$ & https://www.youtube.com/watch?v=XRfgKjP2mdA \\
\hline 2 & Home is its people & $0: 54$ & https://www.youtube.com/watch?v=dimdJd2M6al \\
\hline 3 & $\begin{array}{l}\text { We say no to their } \\
\text { plan for the many }\end{array}$ & $1: 18$ & https://www.youtube.com/watch?v=kFkuYPdlwnc \\
\hline 4 & $\begin{array}{l}\text { Restore injustices - } \\
\text { Support to the } \\
\text { pensioners }\end{array}$ & $1: 06$ & https://www.youtube.com/watch?v=XGplthOnIDc \\
\hline 5 & $\begin{array}{l}\text { Full access to Free } \\
\text { Public Health }\end{array}$ & $0: 25$ & https://www.youtube.com/watch?v=86awhGX09YM \\
\hline 6 & $\begin{array}{l}\text { Enhancement of } \\
\text { Free Public Health }\end{array}$ & $0: 25$ & \\
\hline
\end{tabular}


Visual self-representation strategies of Greek political leaders

\begin{tabular}{|c|c|c|c|}
\hline 7 & $\begin{array}{l}\text { A fair Insurance } \\
\text { system for all }\end{array}$ & $0: 22$ & https://www.youtube.com/watch?v=CFmwKMqJcHk \\
\hline 8 & $\begin{array}{l}\text { Sustainable } \\
\text { Insurance system for } \\
\text { all }\end{array}$ & $0: 24$ & https://www.youtube.com/watch?v=8S5tFjjggB8 \\
\hline 9 & $\begin{array}{l}\text { Free Public } \\
\text { Education for all }\end{array}$ & $0: 41$ & https://www.youtube.com/watch?v=EAA17NUSdCc \\
\hline 10 & $\begin{array}{l}\text { Protection of Labour } \\
\text { Rights }\end{array}$ & $0: 41$ & https://www.youtube.com/watch?v=J7NjYRycems \\
\hline 11 & Equal rights for @ll & $0: 21$ & https://www.youtube.com/watch?v=do3ViQrhzxo \\
\hline 12 & $\begin{array}{l}\text { Support for the } \\
\text { family and the } \\
\text { children }\end{array}$ & $0: 30$ & https://www.youtube.com/watch?v=88TuU3vs92o \\
\hline 13 & $\begin{array}{l}\text { It is the time for the } \\
\text { many }\end{array}$ & $2: 04$ & https://www.youtube.com/watch?v=k440njaxcww \\
\hline 14 & $\begin{array}{l}\text { Regulation of the } \\
\text { broadcasting sector }\end{array}$ & $0: 29$ & https://www.youtube.com/watch?v=CZA9dgKPXCY \\
\hline 15 & $\begin{array}{l}\text { Empowerment of } \\
\text { the Welfare State }\end{array}$ & $0: 28$ & https://www.youtube.com/watch?v=7y9fwKFIpKU \\
\hline
\end{tabular}

Source: Official SYRIZA YouTube channel 
Visual self-representation strategies of Greek political leaders

\section{References:}

Ahler, D. J., Citrin, J., Dougal, M. C. \& Lenz, G. S. (2017). Face value? Experimental evidence that candidate appearance influences electoral choice. Political Behavior, 39(1), 77-102.

Banducci, S. A., Karp, J. A., Thrasher, M. \& Rallings, C. (2008). Ballot photographs as cues in lowinformation elections. Political Psychology, 29(6), 903-917.

Barrett, A. W. \& Barrington, L. W. (2005, Fall). Is a picture worth a thousand words? Newspaper photographs and voter evaluations of political candidates. Press/Politics, 10(4), 98-113.

Bucher, H. \& P. Schumacher. (2006.) "The Relevance of Attention for Selecting News Content. An Eyetracking Study on Attention Patterns in the Reception of Print and Online Media." Communications: The European Journal of Communication Research, 31:347-68.

Cialdini, R. (2006). Influence: The Psychology of Persuasion. New York: Harper Business.

Cmeciu, C. (2016). Facebook Photographic Images: Poltical Tools of Self-Presentation during the 2014 European Parliament Elections in Romania. In: Deželan, T. \& Vobic, I. (eds.) (R)evolutionizing Political Communication through Social Media. USA: IGI Global, pp. 229-253.

Coleman, R. \& Wu, D. (2015). Image and emotion in voter decisions: The affect agenda: Lanham, MD: Lexington Books.

Colliander, J., Marder, B., Falkman, L. L., Madestam, J., Modig, E. \& Sagfossen, S. (2017). The social media balancing act: Testing the use of a balanced self-presentation strategy for politicians using twitter. Computers in Human Behavior, 74, 277-285.

Deligiaouri, A. (2011). Innovations in Greek Political Communication and Consequences: Significant changes from 1981-2009. Estudos em Comunicação, 10: 45-68.

Deligiaouri, A. \& Symeonidis, P. (2010) “Youtube debate": a new era of internetized television Politics?. International Journal of E-Politics, 1(2), 46-64.

Entman, R. M. (1993). Framing: Toward Clarification of a Fractured Paradigm. Journal of Communication, $43(4): 51-58$.

Featherstone, K. \& Papadimitriou, D. (2019) Prime Ministers in Greece. The Paradox of Power. Athens:

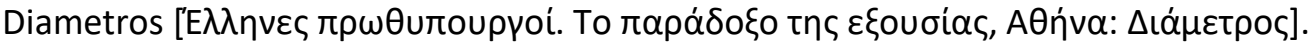


Visual self-representation strategies of Greek political leaders

Goodnow, T. (2013). Facing off: A comparative analysis of Obama and Romney Facebook timeline photographs. American Behavioral Scientist, 57(11): 1584-1595.

Goffman, E. (1959). The presentation of self in everyday life. New York: Doubleday.

Grabe, M. E. \& Bucy, E. P. (2009). Image bite politics: News and the visual framing of elections: Oxford University Press.

Graber, D. (1996). Say It with Pictures. Annals of the American Academy of Political and Social Science, 546:85-96.

Grusin, R. (2009). YouTube at the end of new media. In Snickars, P. \& Vonderau, P. (eds.), The YouTube Reader. Stockholm, Sweden: National Library of Sweden, pp. 60-67.

Gueorguieva, V. (2008). Voters, MySpace, and YouTube: The impact of alternative communication channels on the 2006 election cycle and beyond. Social Science Computer Review, 26, 288-300.

Gupta, A. (2013). "The Shift from Words to Pictures and Implications for Digital Marketers." Forbes. https://www.forbes.com/sites/onmarketing/2013/07/02/the-shift-from-words-to-pictures-andimplications-for-digital-marketers/

Hertog, J. K. \& McLeod, D. M. (2001) A multiperspectival approach to framing analysis: A field guide. In Reese, S. D., Gandy, O. H. \& Grant, A. E. (eds.), Framing public life, Mahwah, NJ: Lawrence Erlbaum, pp. 139-162.

Holtz-Bacha, C. \& Johansson, B. (2017). Election posters around the globe: Political campaigning in the public space. Cham: Springer.

Jackson, N. \& Lilleker, D. (2011). Microblogging, constituency service and impression management: UK MPs and the use of Twitter. The Journal of Legislative Studies, 17(1), 86-105.

Jackson D., Lilleker, D. \& Veneti, A. (2019). Report: Social Media Use in Political Communication in $\begin{array}{llll}\text { Greece. } & \text { Bournemouth } & \text { University. }\end{array}$ 
Visual self-representation strategies of Greek political leaders

at:https://www.bournemouth.ac.uk/sites/default/files/asset/document/Report-Use-of-Social-

Media-in-politics-in-Greece.pdf

Kaid, L. L. (1998). Videostyle and the effects of the 1996 presidential campaign advertising. In R. E. Denton, Jr., R. E. (ed.), The 1996 presidential campaign: A communication perspective. Westport, CT: Praeger. pp. 143-159.

Kaid, L. L. \& Johnston, A. (2001). Videostyle in presidential campaigns: Style and content of televised political advertising. Santa Barbara, CA: Praeger.

Kaid, L. L. \& Holtz-Bacha, C. (2006). Television advertising and democratic systems around the world: A comparison of videostyle content and effects. In Kaid, L. L. \& C. Holtz-Bacha, C. (eds.), The Sage handbook of political advertising. Thousand Oaks, CA: Sage, pp. 445-459.

Kreiss, D., Lawrence, R.G. \& McGregor, S.C. (2018). In Their Own Words: Political Practitioner Accounts of Candidates, Audiences, Affordances, Genres, and Timing in Strategic Social Media Use, Political Communication, 35 (1), 8-31.

Langer, A. I. (2013). The personalisation of politics in the UK: Mediated leadership from Attlee to Cameron. Manchester, England: Manchester University Press.

Lee, J. (2016). President's Visual Presentation in Their Official Photos: A Cross-Cultural Analysis of the US and South Korea. Cogent Arts \& Humanities, 3 (1):1-14.

Lilleker, D. G. \& Koc-Michalska, K. (2013). Online political communication strategies: MEPs, erepresentation, and self-representation. Journal of Information Technology \& Politics, 10(2), 190-207.

Lyrintis, C. (2007). Political parties in post-junta Greece: A case of 'bureaucratic clientelism'?. Western European Politics, 7(2): 99-118.

Marland, A. (2012). Political photography, journalism, and framing in the digital age: The management of visual media by the prime minister of Canada. The International Journal of Press/Politics, 17(2), 214233. 
Visual self-representation strategies of Greek political leaders

Moschonas, G. (2002). In the Name of Social Democracy. The Great Transformation: 1945 to the Present. London: Verso.

Moschonas, G. (2004). Electoral Discourse and Electoral Strategies of Socialist Parties in Europe. The

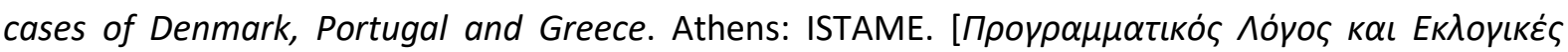

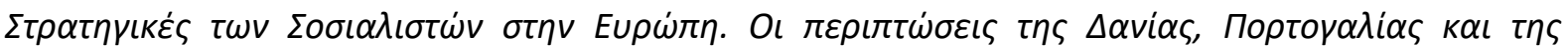

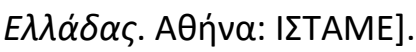

Muñoz, C. L, \& Towner, T. L. (2017). The image is the message: Instagram marketing and the 2016 presidential primary season. Journal of Political Marketing, 16(3-4), 290-318.

New Democracy YouTube Channel (2019) Available at: https://www.youtube.com/user/NDWebTV

Novelli, E., Rafter, K., Poulakidakos, S., Veneti, A., Verissimo, I., Alvares, C., Sammut, C., Triga, V. \& Milioni, D.L. (2017). Representations of the economic crisis and austerity politics. In Holtz-Bacha, C., Novelli, E. \& Rafter, K. (eds.) Political Advertising in the 2014 European Parliament Election. Palgrave McMillan. pp.57-80.

Papathanasopoulos, S. (2007). Political Communication and Professionalization in Greece. In Negrine, R., Mancini, P., Holtz-Bacha, C. \& Papathanasopoulos, S. (eds). The Professionalization of Political Communication. UK: Intellect Books, pp.127-143.

Poulakidakos, S. \& Giannouli, I. (2019). Greek Political Leaders on Instagram: Between "Soft" and "Hard" Personalization. In Veneti, A., Jackson, D. \& Lilleker, D. G. (eds.). Visual Political Communication. London: Palgrave, pp.187-206.

Reif, K. \& Schmit, H. (1980). Nine second-order national elections- A conceptual framework for the analysis of European election results. European Journal of Political Research, 8(1), 3-44.

Ridout, T.V., Franklin Fowler, E. \& Branstetter, J. (2010). Political Advertising in the 21st Century: The Rise of the YouTube Ad. Paper presented at the American Political Science Association, September 25, 2010, Washington, D.C (available at file:///C:/Users/Anastasia/Downloads/SSRN-id1642853.pdf) Rodriguez, L. \& Dimitrova, D. V. (2011). The levels of visual framing. Journal of Visual Literacy, 30(1), $48-65$. 
Visual self-representation strategies of Greek political leaders

Rosenberg, S. W., Bohan, L., McCafferty, P. \& Harris, K. (1986). The Image and the Vote: The Effect of Candidate Presentation on Voter Preference. American Journal of Political Science, 30 (2),108-27.

Russmann, U. \& Svensson. J. (2017). Interaction on Instagram? Glimpses from the 2014 Swedish Elections. International Journal of E-Politics, 8 (1),50-65.

Schill, D. (2012). The Visual Image and the Political Image: A Review of Visual Communication Research in the Field of Political Communication. Review of Communication, 12 (2),118-42.

Schram, A.B. (2014). A Mixed Methods Content Analysis of the Research Literature in Science Education, International Journal of Science Education, 36(15),2619-2638.

Stanyer, J. (2008). Elected representatives, online self-presentation and the personal vote: Party, personality and webstyles in the United States and United Kingdom. Information, Communication \& Society, 11(3), 414-432.

Statista (2019) YouTube - Statistics \& Facts Available at https://www.statista.com/topics/2019/youtube/

Strand, R.T. \& Schill, D. (2019). The Visual Presidency of Donald Trump's First Hundred Days: Political Image-Making and Digital Media. In Veneti, A., Jackson, D. \& Lilleker, D.G. (eds.). Visual Political Communication. London: Palgrave, pp.167-186.

SYRIZA YouTube Channel (2019) Available at https://www.youtube.com/user/officialsyriza

Veneti, A. \& Poulakidakos, S. (2019) Political campaigns of the $7^{\text {th }}$ July elections: New Democracy and SYRIZA in opposing roles. At Efimerida ton Sintakton https://www.efsyn.gr/politiki/200770 otan-

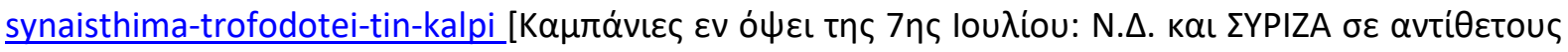

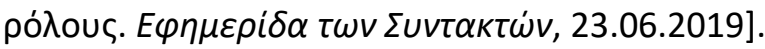

Veneti, A. (2020). A Brief Semiotic Analysis of the Visual Image of the Political Leaders Through the National Elections 2019 Political Advertisements. In loannidis, P. \& Tsaousakis, E. (eds). 2019. The First

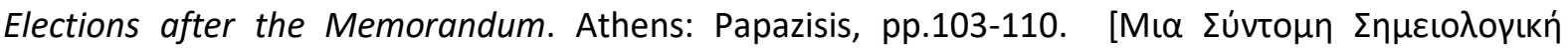


Visual self-representation strategies of Greek political leaders

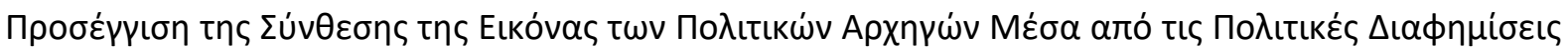

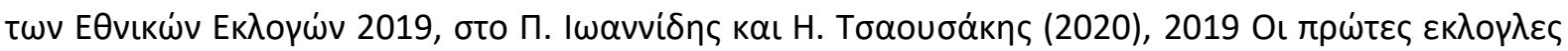

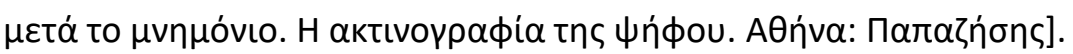

Vesnic-Alujevic, L. \& Van Bauwel, S. (2014). YouTube: A Political Advertising Tool? A Case Study of the Use of YouTube in the Campaign for the European Parliament Elections, Journal of Political Marketing, 13(3), 195-212.

INSERT ANY TABLES / FIGS / PICTURES / ILLUSTRATIONS / TABLES HERE (or attach them in separate documents) 


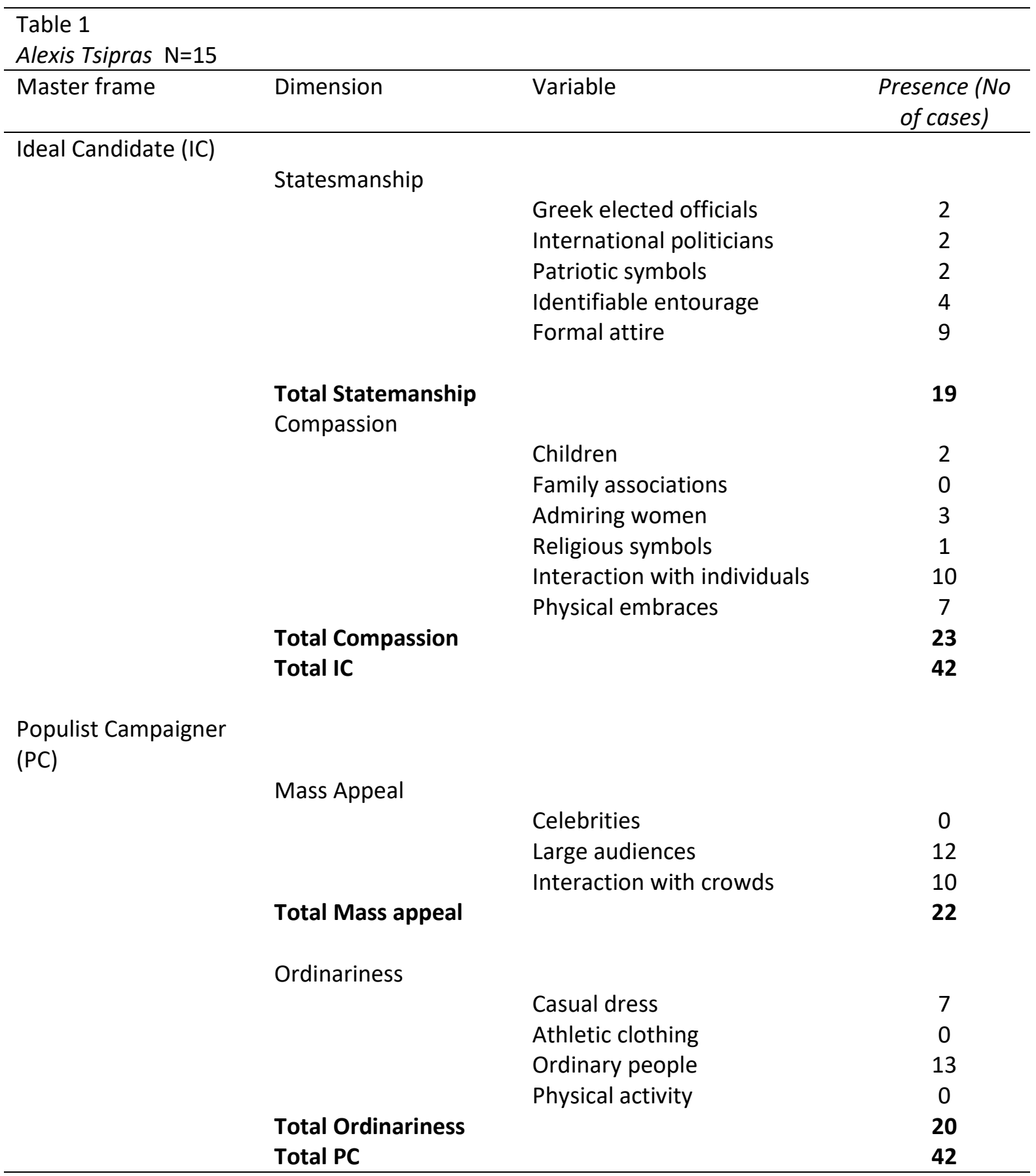

Table 2. Camera angle: A. Tsipras

\begin{tabular}{l|l|l|l} 
Frequency & Percent & $\begin{array}{c}\text { Valid } \\
\text { Percent }\end{array}$ & $\begin{array}{c}\text { Cumulative } \\
\text { Percent }\end{array}$ \\
\hline
\end{tabular}




\begin{tabular}{|l|r|r|r|r} 
Valid & 1 & 6.7 & 6.7 & 6.7 \\
$\begin{array}{l}\text { Looking } \\
\text { directly } \\
\text { to the } \\
\text { camera }\end{array}$ & 10 & 66.7 & 66.7 & 73.3 \\
$\begin{array}{l}\text { Not } \\
\text { looking } \\
\text { to the } \\
\text { camera }\end{array}$ & 4 & 26.7 & 26.7 & 100.0 \\
\hline Mixed & 15 & 100.0 & 100.0 & \\
\hline Total & & & & \\
\hline
\end{tabular}

\begin{tabular}{|c|c|c|c|}
\hline $\begin{array}{l}\text { Table } 3 \\
\text { Kyriakos Mitsotakis }\end{array}$ & & & \\
\hline Master frame & Dimension & Variable & $\begin{array}{l}\text { Presence (No } \\
\text { of cases) }\end{array}$ \\
\hline Ideal Candidate & & & \\
\hline & Statesmanship & & \\
\hline & & Greek elected officials & 3 \\
\hline & & International politicians & 1 \\
\hline & & Patriotic symbols & 5 \\
\hline & & Identifiable entourage & 3 \\
\hline & & Formal attire & 5 \\
\hline & Total Statemanship & & 17 \\
\hline & Compassion & & \\
\hline & & Children & 3 \\
\hline & & Family associations & 0 \\
\hline & & Admiring women & 3 \\
\hline & & Religious symbols & 0 \\
\hline & & Interaction with individuals & 5 \\
\hline & & Physical embraces & 5 \\
\hline & Total Compassion & & 16 \\
\hline & Total IC & & 33 \\
\hline Populist Campaigner & & & \\
\hline & Mass Appeal & & \\
\hline & & Celebrities & 0 \\
\hline & & Large audiences & 5 \\
\hline & & Interaction with crowds & 4 \\
\hline & Total Mass Appeal & & 9 \\
\hline & Ordinariness & & \\
\hline & & Casual dress & 3 \\
\hline & & Athletic clothing & 0 \\
\hline & & Ordinary people & 5 \\
\hline & & Physical activity & 0 \\
\hline & Total Ordinariness & & 8 \\
\hline & Total PC & & 17 \\
\hline
\end{tabular}

